\title{
Bacillus xerothermodurans sp. nov., a Species Forming Endospores Extremely Resistant to Dry Heat
}

\author{
WALTER W. BOND AND MARTIN S. FAVERO \\ Special Investigations Section, Phoenix Laboratories Division, Bureau of Epidemiology, Center for Disease \\ Control, Phoenix, Arizona 85014
}

\begin{abstract}
An unusual mesophilic bacillus was isolated from soil, and a cleaned spore preparation of this organism showed extreme resistance to dry heat $\left(D_{125^{\circ} \mathrm{C}}=139\right.$ $\mathrm{h}, \mathrm{D}_{130^{\circ} \mathrm{C}}=54 \mathrm{~h}, \mathrm{D}_{135^{\circ} \mathrm{C}}=24 \mathrm{~h}, \mathrm{D}_{140^{\circ} \mathrm{C}}=13 \mathrm{~h}, \mathrm{D}_{145^{\circ} \mathrm{C}}=8 \mathrm{~h}, \mathrm{D}_{150^{\circ} \mathrm{C}}=2.5 \mathrm{~h}$; where $\mathrm{D}=$ time at temperature effecting $90 \%$ reduction in viable count); and relative sensitivity to moist heat $\left(\mathrm{D}_{80^{\circ} \mathrm{C}}=61 \mathrm{~min}\right)$. The biochemical tests, exterior and interior spore morphology, and growth characteristics of this organism do not fit those of any of the presently described species of bacteria. Consequently, we regard this organism as belonging to a new species, for which we propose the name Bacillus xerothermodurans. The type strain of this species has been deposited in the American Type Culture Collection as ATCC 27380.
\end{abstract}

The degree to which bacterial endospores are resistant to dry heat is often significantly different from their resistance to moist heat. For example, spores of Bacillus stearothermophilus are resistant to moist heat but are relatively sensitive to dry heat. Conversely, spores of $B a$ cillus subtilis subsp. niger are resistant to dry heat and are relatively sensitive to moist heat. Even though the accumulated knowledge of thermal resistance parameters is large, the major portion of existing data deals with moistheat exposures. In the late 1950's, the problem of interplanetary contamination and subsequent studies of spacecraft decontamination and sterilization procedures prompted many large-scale investigations into the precise inactivation kinetics effected by dry heat.

While studying the comparative dry-heat inactivation rates of mixed, naturally occurring bacterial spores in soil (2), we reported the isolation of an unusual, slow-growing sporeformer from soil heated at $125^{\circ} \mathrm{C}$ for $48 \mathrm{~h}$. A cleaned spore preparation showed extreme resistance to dry heat $\left[\mathrm{D}_{125^{\circ} \mathrm{C}}=139 \mathrm{~h}, \mathrm{D}_{130^{\circ} \mathrm{C}}=54\right.$ $\mathrm{h}, \mathrm{D}_{135^{\circ} \mathrm{C}}=24 \mathrm{~h}, \mathrm{D}_{140^{\circ} \mathrm{C}}=13 \mathrm{~h}, \mathrm{D}_{145^{\circ} \mathrm{C}}=8 \mathrm{~h}, \mathrm{D}_{150^{\circ} \mathrm{C}}$ $=2.5 \mathrm{~h}$ (a $\mathrm{D}$ value is defined as time at temperature effecting a $90 \%$ reduction in viable count)] (1). We had previously shown $(2,3$; unpublished data) $\mathrm{D}_{125^{\circ} \mathrm{C}}$ values for $B$. subtilis subsp. niger spores ranging from 8 to $50 \mathrm{~min}$, depending upon the type of sporulation medium and assay system used. In addition, $D_{125^{\circ} \mathrm{C}}$ values of subcultured environmental isolates from spacecraft, assembly areas, and soil ranged from $<5$ to $100 \mathrm{~min}$. The dry-heat resistance level of the new isolate's spores was approximately 80 times higher than that of any previously tested spores using comparable experimental systems.
Naturally occurring spores are generally thought to be more resistant to heat than their subcultured counterparts; however, Puleo et al. (7) reported a maximum $D_{125^{\circ} \mathrm{C}}$ value (dry heat) of $6.3 \mathrm{~h}$ in a study of heterogeneous spore populations collected from air, a value 22 times lower than that of the new isolate's spores. The resistance level of the new isolate's spores to moist heat was shown to be relatively low $\left(D_{80^{\circ} \mathrm{C}}\right.$ $=61 \mathrm{~min})(2)$.

The purpose of this paper is to present the results of a taxonomic study of the new isolate.

(Initial observations of spore-surface morphology by electron microscopy [performed at Sandia Laboratories, Albuquerque, N.M.] and dry-heat-resistance determinations at $125^{\circ} \mathrm{C}$ were informally presented at the Fifth International Spore Conference, Fontana, Wis., 8-10 October 1971, at the request of $\mathrm{H}$. Orin Halvorson. The thermal-resistance profile data were presented at the Sixth International Spore Conference, Michigan State University, East Lansing, Michigan, 10-13 October 1974.)

\section{MATERIALS AND METHODS}

Soil sample preparation. Raw sandy soil collected in the vicinity of Cape Kennedy, Fla., was washed with $95 \%$ ethyl alcohol through a graded series of stainless-steel sieves, the smallest opening being 43 $\mu \mathrm{m}$. The resultant spore and soil concentrations were $2.7 \times 10^{5} / \mathrm{ml}$ and $0.03 \mathrm{~g} / \mathrm{ml}$, respectively, as determined by methods reported earlier (2).

Determination of dry-heat inactivation kinetics. Portions $(0.1 \mathrm{ml})$ of the soil suspension were applied to stainless-steel coupons $(1.27$ by $1.27 \mathrm{~cm})$, and the dry-heat resistance level of the spore population was determined using a forced-air oven in two methods described previously $(3,4)$. 
Isolation of the culture. During an end-point determination with this naturally occurring spore population in which survivors after the 48 - $h$ interval at $125^{\circ} \mathrm{C}$ were recovered in broth (3), a slow-growing sporeformer was isolated after 1 month of incubation at $32^{\circ} \mathrm{C}$. Positive tubes were recognized only when vigorously agitated to show a clear, compact, mucoid sediment with no turbidity in the supernatant broth. When subcultured on Trypticase soy agar (TSA; BBL) supplemented with $0.2 \%$ (wt/vol) yeast extract and $0.1 \%$ (wt/vol) soluble starch, growth and sporulation were also slow at $32^{\circ} \mathrm{C}$, requiring 10 to 14 days to achieve detectable levels of sporulation (2).

Biochemical tests. The isolate was subjected to a battery of biochemical tests for the identification of Bacillus spp. (2), by the methodology of Gordon et al. (5) unless otherwise noted. Tests performed were (i) growth in 2,4 , and $10 \% \mathrm{NaCl}$ broth, (ii) production of catalase, (iii) motility, (iv) utilization of citrate, (v) hydrolysis of starch (soluble starch), gelatin or casein, (vi) production of acetylmethylcarbinol or indole, (vii) reduction of nitrate or methylene blue, (viii) utilization of arabinose, glucose, lactose, sorbitol, rhamnose, mannitol or xylose, (ix) anaerobic growth (supplemented TSA in a Brewer anaerobic jar [BBL] for 14 days at $32^{\circ} \mathrm{C}$ ), and (x) growth at $45^{\circ} \mathrm{C}$.

\section{RESULTS}

When subcultured, the isolate exhibited pleomorphism in the gram-variable, rod-shaped, nonmotile vegetative cells ( 0.7 to 1.2 by 1.6 to $2.8 \mu \mathrm{m}$ ) with spherical to slightly oval, central to subterminal spores having rough, stainable walls. After leaving swollen sporangia, the spores appeared, by observation with light microscopy, to increase in size from 1.2 to approximately $1.7 \mu \mathrm{m}$ while assuming a more oval shape. Pleomorphısm in vegetative cells became more marked in older cultures, and the highly sculptured spore surfaces were plainly visible using light microscopy; less stainable forms showing surface texture were most likely spore-wall debris left after germination. Figure 1 is a scanning electron photomicrograph of a spore showing the typical surface morphology in detail. The surface honeycomb pattern of polygonal depressions surrounded by straight ridges is similar to that found in other reports in the literature $(6,8)$ dealing with distinctly oval or cylindrical spores. Birdsell (Abstr. Annu. Meet. Am. Soc. Microbiol. 1974, G212, p. 55; unpublished data), in his ultrastructure study of the relatively large spore of ATCC 27380 , found that sectioning revealed an irregular, thick outer spore coat composed of globular subunits and an unusual laminated inner spore coat containing up to nine distinct layers, as shown in Fig. 2. It has been speculated that these spore coats may serve as barriers to mois-

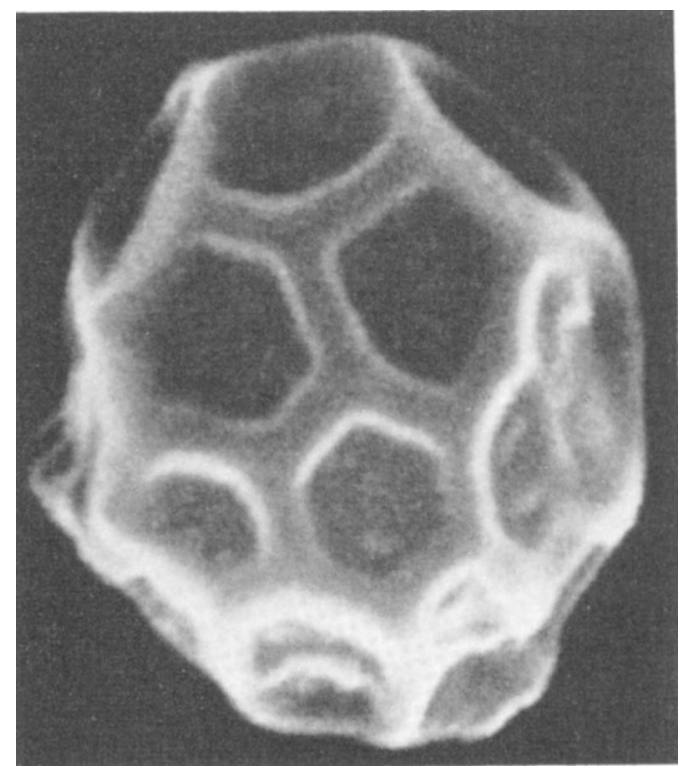

Fig. 1. Scanning electron micrograph of a spore of Bacillus xerothermodurans ATCC 27380. Magnification, $\times 30,000$. Courtesy of Sandia Laboratories, Albuquerque, N.M.

ture loss during heating and may thereby account for the extreme resistance to dry heat.

Our preliminary studies in 1971 (2) showed that ATCC 27380 was rather physiologically inactive and that it did not fit any described pattern of reaction. From the battery of biochemical tests, the only positive reactions shown were growth in 2,4 , or $10 \% \mathrm{NaCl}$ broth, aerobic growth, and production of catalase. $R$. E. Gordon (personal communication) observed that cultures of the isolate obtained in 1971 and subsequently transferred at intervals on soil extract agar have gained physiological capabilities (ability to grow in various media) not observed initially but still have retained the relative biochemical inactivity corresponding to no existing pattern. Also, Gordon has observed starch hydrolysis when potato starch rather than soluble starch was used as the substrate. Youvan, Holmquist, and Jukes (personal communication; D. Youvan, M. Watanabe, and R. Holmquist, in R. Holmquist (ed.), Life sciences and space research, vol. 15, in press) have recently examined spores of the isolate and confirmed the extreme resistance to dry heat $\left(\mathrm{D}_{138^{\circ} \mathrm{C}}=17 \mathrm{~h}\right)$.

\section{DISCUSSION}

By virtue of (i) the aerobic, sporeforming nature of isolate, (ii) its unusual external and 

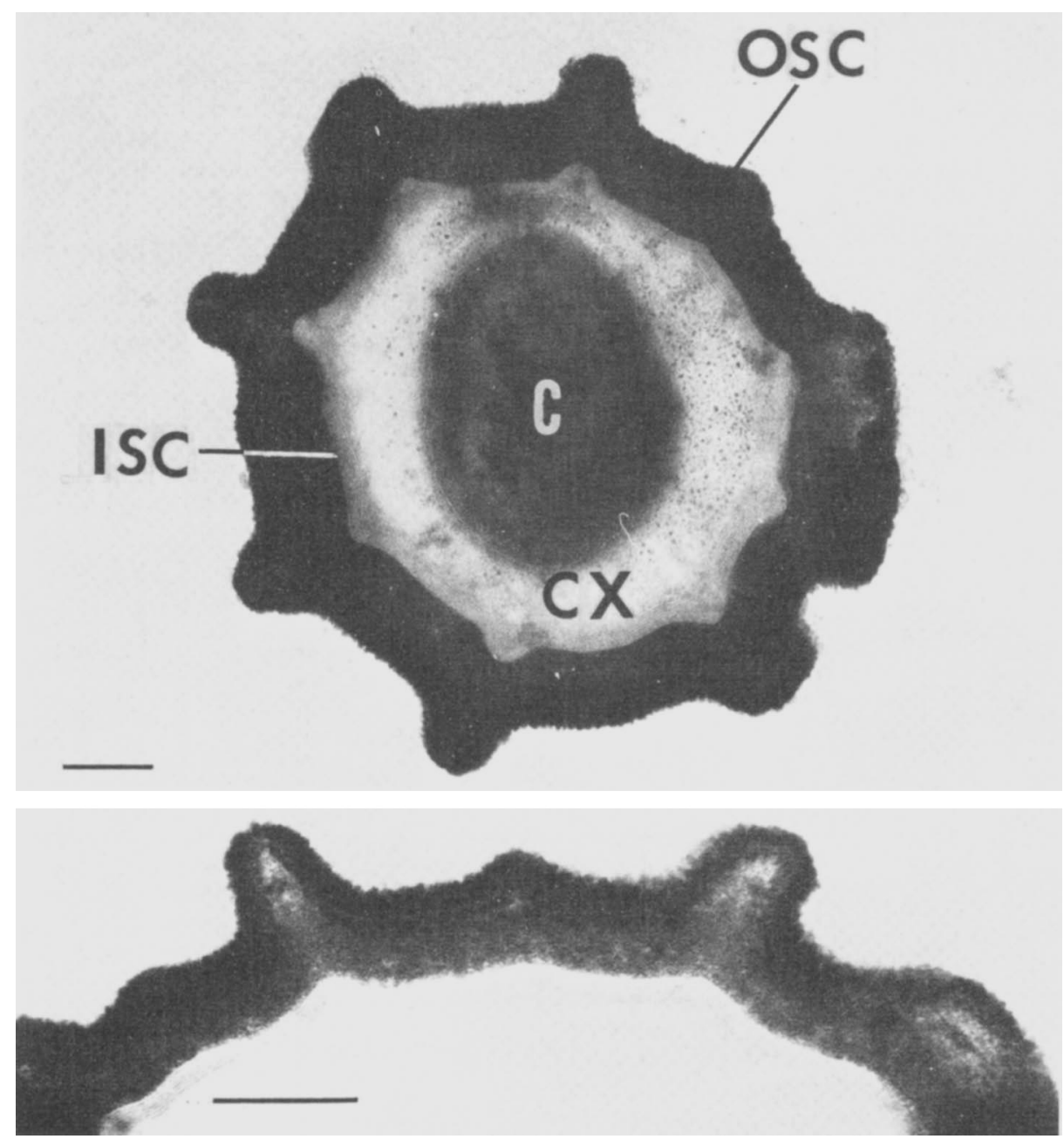

FIG. 2. Thin-section electron micrograph of a spore of Bacillus xerothermodurans ATCC 27380. Top: Magnification, $\times 50,000$. Bar represents $20 \mathrm{~nm}$. Abbreviations: $C$, core; $C X$, cortex; ISC, inner spore coat; OSC, outer spore coat. Bottom: Magnification, $\times 82,000$. Bar represents $20 \mathrm{~nm}$.

internal spore morphology, (iii) the relative biochemical inactivity of the culture, and (iv) the unique and extreme magnitude of spore resistance to dry heat, we regard this organism as a new and distinct species of the genus Bacil$l u s$, and for this new species we propose the name Bacillus xerothermodurans (Gr. adj. xeros dry; Gr. adj. thermus hot; L. part adj. durans hardening, resisting; M. L. adj. xerothermodurans [intended to mean] resisting dry heat). The type strain is American Type Culture Collection (ATCC) strain 27380.

The magnitude of the dry-heat resistance, the need for heat activation for maximum ger- mination $(1,2)$, and the difference in resistance levels between dry and moist heat of the spores of this new species may make them valuable tools in studies of sporulation, germination, dormancy, and heat-inactivation mechanisms.

\section{ACKNOWLEDGMENTS}

We wish to thank Ruth E. Gordon, Rutgers University, for her patience and very generous assistance. Gratitude is also expressed to D. C. Birdsell, University of Florida, for providing opinions and thin-section electron photomicrographs of the isolate and to Douglas Youvan, Richard Holmquist, and Thomas Jukes, Space Science Laboratory, University of California, for sharing their observations. The late H. Orin Halvorson is remembered for his encouragement. 
Services were provided in support of the planetary quarantine requirements of the National Aeronautics and Space Administration under contract W-13,062.

\section{REPRINT REQUESTS}

Address reprint requests to: Walter W. Bond, Phoenix Laboratories Division, Center for Disease Control, 4402 North Seventh St., Phoenix, AZ 85014.

\section{LITERATURE CITED}

1. Bond, W. W., and M. S. Favero. 1975. Thermal profile of a Bacillus species (ATCC 27380) extremely resistant to dry heat. Appl. Microbiol. 29:859-860.

2. Bond, W. W., M. S. Favero, and M. R. Korber. 1973. Bacillus sp. ATCC 27380: a spore with extreme resistance to dry heat. Appl. Microbiol. 26:614-616.

3. Bond, W. W., M. S. Favero, N. J. Petersen, and J. H. Marshall, 1971. Relative frequency distribution of $D_{125^{\circ} \mathrm{C}}$ values for spore isolates from the Mariner-
Mars 1969 spacecraft. Appl. Microbiol. 21:832-836.

4. Bond, W. W., M. S. Favero, N. J. Petersen, and J. H. Marshall. 1970. Dry-heat inactivation kinetics of naturally occurring spore populations. Appl. Microbiol. 20:573-578.

5. Gordon, R. E., W. C. Haynes, and C. H-N. Pang. 1973. The genus Bacillus. Agricultural Handbook no. 427. U.S. Department of Agriculture, Washington, D.C.

6. Holt, S. C., and E. R. Leadbetter. 1969. Comparative ultrastructure of selected aerobic spore-forming bacteria: a freeze-etching study. Bacteriol. Rev. 33:346378.

7. Puleo, J. R., M. S. Favero, G. S. Oxborrow, and C. M. Herring. 1975. Method for collecting naturally occurring airborne bacterial spores for determining their thermal resistance. Appl. Microbiol. 30:786-790.

8. Robinow, C. F. 1960. Morphology of bacterial spores, their development and germination, p. 207-248. In I. C. Gunsalus and R. Y. Stanier (ed.), The bacteria vol. 1. Academic Press Inc., New York. 